\title{
Benzyl Adenine and Paclobutrazol Coupled with Shoot Decapitation Affects Growth and Flowering in Barleria cristata L. 'Alba'
}

\author{
Hitesh Bhardwaj ${ }^{2 *}$, Priyanka Thakur ${ }^{1}$, S. R. Dhiman ${ }^{2}$, Y. C. Gupta ${ }^{2}$, \\ B. S. Dilta ${ }^{3}$, A. Thakur $^{4}$ and Rahul Chandel ${ }^{2}$ \\ ${ }^{I}$ Regional Horticulture Research and Training Station, Dhaulakuan, Sirmour, India \\ ${ }^{2}$ Department of Floriculture and Landscape Architecture \\ ${ }^{3}$ Seed Production Department, UHF, Nauni, India \\ ${ }^{4}$ Forest Research Institute, Dehradun (UK), India \\ Dr YS Parmar University of Horticulture and Forestry, Nauni, Solan 173230 HP, India \\ *Corresponding author
}

\begin{tabular}{|l|}
\hline K e y w o r d s \\
Barleria, Pinching, \\
BAP, Paclobutrazol, \\
Growth, Flowering, \\
Pot presentability, \\
Cytokinins, \\
PGR \\
\hline Article Info \\
\hline Accepted: \\
15 January 2020 \\
Available Online: \\
10 February 2020 \\
\hline
\end{tabular}

\section{A B S T R A C T}

Barleria cristata L. 'Alba' is a white flowering perennial shrub used as a hedge and specimen plant in landscaping and has potential of being grown as a pot plant too. The study was conducted on this plant to ascertain the effect of benzyl adenine (BA), paclobutrazol with pinching (shoot decapitation) for making it a presentable pot plant. The experiment was laid out in a Completely Randomized Design (Factorial) using three levels of pinching i.e. no pinching(control), single pinching, double pinching with three levels of each BA (drench) and paclobutrazol (foliar spray) i.e. 0 ppm, $100 \mathrm{ppm}$ and $200 \mathrm{ppm}$ each. The results revealed that the double pinched plants coupled with the application of BA @ 200 ppm and paclobutrazol @ 200 ppm had recorded maximum values for number of side shoots per plant (25.00), number of leaves per plant (110.80), number of flower clusters per plant (28.87), number of flowers per cluster (11.07), number of flowers per plant opened at a time (28.93) and duration of flowering (36.33). However, maximum pot presentability score (88.00) was found in those plants which exhibited optimum plant height $(28.39 \mathrm{~cm})$ and plant spread $(30.81 \mathrm{~cm})$ along with other pot presentability attributes with the application of double pinching, paclobutrazol and BA @ 100 ppm each. In the light of the presentability attributes of the Barleria in the pots, treatment combination of double pinching, BA (100 ppm) and paclobutrazol (100 ppm) found to be most suitable.

\section{Introduction}

Barleria is a diverse and genus of flowering shrubs of family Acanthaceae. Barleria cristata L. 'Alba' commonly known as
'White Philippine Violet' is perennial and prefers tropical and subtropical climate with maximum sunlight, well-drained soil with $\mathrm{pH}$ of 6-7 for good growth and flowering. This is native to India and widely distributed across 
the country i.e., from lower hills of West Bengal, South and West Deccan plateau, Konkan, Mangelee-Ghat, Bababoodan hills, Malabar, Nilgiris, Ootacamand, Bombay Ghats, Punjab Kirana hills, Jabalpur and North-West Himalayan region. It is easily propagated by seeds and terminal cuttings.

Barleria cristata L. 'Alba' is commonly grown in the garden as a hedge plant, utilized for making shrubbery borders and commercially grown for loose flower production in South India (Bhattacharjee, 1980). It is used for making garlands, adorning the hair of women and used for religious and ceremonial offerings. Its capsules are used in ornamental decorations such as greeting cards, wall pictures, dry flower arrangements and other gift items. This plant have some therapeutic uses properties; like leaves against toothache, roots as well as leaves have anti-inflammatory properties, cure for anaemia and rheumatism. Besides, its seeds are antidote against snake bite and its infusion is therapeutic in cough (Pullaiah, 2006).

Considering demands of B. cristata L. 'Alba' in floriculture and landscaping, the present study was undertaken to standardize the pinching (shoot decapitation) methods and applications of benzyl adenine and paclobutrazol on growth and flowering of this species.

\section{Materials and Methods}

The present investigation was carried out during the year June 2017 to December 2018 at the experimental farm of Regional Horticultural Research and Training Station, Dhaulakuan, Sirmaur under the aegis of Dr YSPUHF (H.P.), India, which is situated at an altitude of $468 \mathrm{~m}$ amsl in the sub-tropical, sub-montane and low-hill zone of Himachal Pradesh and located along-side the Nahan-
Paonta road (NH-72) having 30'30'20" of Latitude $\mathrm{N}$ and $77^{\circ} 20^{\prime} 30^{\prime \prime}$ of Longitude E.

Straight softwood terminal cuttings with 4-5 nodes, $8-10 \mathrm{~cm}$ long of pencil thickness were taken from new growth of the plants in the native habitats in Paonta- Doon valley during June, 2017. These terminal cuttings were dipped in solution of Dithane M-45 (0.2\%) and Crbendazim (0.1\%) for 4-5 minutes. The cuttings were prepared for rooting by removing the lower leaves and giving a slanting cut at the basal node before planting in beds of the propagation chamber filled with cocopeat and sand in the ratio of $1: 1(\mathrm{v} / \mathrm{v})$. To facilitate optimum rooting, basal portion of cuttings was dipped in NAA (500 ppm) solution for approximately 30 seconds before planting of cuttings in the beds. Planting of cuttings was done in such a fashion so that they do not touch each other. Just after planting, cuttings were irrigated lightly. Thereafter for development of quality roots these were maintained under artificial mist until rooting which took around in 20-25 days. An application of NPK (18:18:18) @ $1 \mathrm{~g} /$ litre were applied at fortnightly intervals and these plants were maintained in pots for one year.

Potting medium was prepared by mix of soil with well rotten farm yard manure (FYM) and sand in the ratio of $2: 1: 1, \mathrm{v} / \mathrm{v}$. The healthy, disease free and stocky rooted cuttings/plants of Barleria cristata L. 'Alba' were selected and transplanted in pots $(8 \mathrm{~cm}$ diameter $)$ containing soil, sand and FYM in the ratio of $2: 1: 1 \mathrm{v} / \mathrm{v}$ on $27^{\text {th }}$ July, 2017. After planting, the medium around the stem of the plant was pressed gently with the help of hands. Thorough watering was given immediately after planting. Intercultural operations including irrigation, hoeing and weeding, fertigation of NPK, spraying against insectpest and diseases carried out. Plants were maintained in pots until $26^{\text {th }}$ July, 2018 for 
proper vegetative growth. Thereafter, all the plants in pots were pruned from top leaving behind approximately $15 \mathrm{~cm}$.

Treatments of shoot decapitation; which will be termed as pinching in further text, application of Benzyl adenine (BA) and Paclobutrazol doses were applied to $B$. cristata L. 'Alba'. The experiment was laid out in Complete Randomized design (CRD) factorial having treatment combinations of pinching (No pinching, Single pinching, Double pinching), Benzyl adenine $(0,100$, 200ppm) and Paclobutrazol (0,100, 200ppm).

Stock solution of $1000 \mathrm{ppm}$ was prepared by dissolving $1000 \mathrm{mg}$ of benzyladenine and paclobutrazol in $5 \mathrm{ml}$ of $95 \%$ ethanol and final volume of one litre was prepared by addition of distilled water. Further this stock solution was used for preparation of 100 and $200 \mathrm{ppm}$ strength of BA and paclobutrazol solution in water.

The plants in pots were drenched with BAP the solution of required concentration on $28^{\text {th }}$ August, 2018 and paclobutrazol solution of required concentration sprayed on 29 Sep, 2018. Pinching or shoot decapitation has role in loosing apical dominance. The treatment of single pinching was given treatment wise by removing the terminal shoot at 4-5 node stage in order to produce uniform side shoots on $28^{\text {th }}$ September, 2017. The treatment of double pinching was done treatment wise in all the secondary shoots at 3-4 node stage in order to produce maximum side shoots after 20-25 days of single pinching. Following observation was taken:

Plant height $(\mathrm{cm})$

Number of side shoots per plant

Number of leaves per plant at the time of flowering

Number of days taken for visible bud formation

Number of days taken for flowering
Flower size $(\mathrm{cm})$ was recorded as the average of distance between the petals in East to West and North to South direction.

Number of flower clusters per plant

Number of flowers per cluster was total number of opened flowers produced per cluster.

Number of flowers opened at a time per plant: This observation was recorded as the total number of flowers in a plant which remained open a time.

Duration of flowering (days) was recorded as the time taken in days from opening of first flower till the anthesis of last flower.

Plant spread $(\mathrm{cm})$ was measured as average of the distance between outermost side shoots in east to west and north to south directions.

Quality of pot plants was evaluated on the basis of Point System modified after Conover (1986). The parameters studied and points allotted to each parameter out of 100 were given in Table 1 .

Data were tested for homogeneity and normality and analyzed in OPSTAT Software for ANOVA of CRD factorial. Means with significant differences (0.05) were compared for all parameters.

\section{Results and Discussion}

Result showed significant effect of pinching (P), benzyl adenine (BA), paclobutrazol (PBZ) on vegetative and flowering characteristics of Barleria cristata L. 'Alba' plants. Among different pinching method used, double pinching proved best for most of the growth and flowering parameters studied (Table 1, 2\&3). As far as vegetative growth and flowering are concerned, different parameter like; number of side shoots (21.30), number of leaves (91.37), number of flower per cluster (9.15), number of flower cluster per plant (25.37), number of flower opened at 
a time per plant (24.27), plant spread (27.52 $\mathrm{cm}$ ), duration of flowering (33.32) and pot presentability score (78.89) were best in this method. This could be due to the superiority of apical dominance theory which describes that loss of production of auxins due to decapitation of shoots by double pinching culminates the role of apical control and accordingly there is development of increased lateral buds (Kumar and Purohit, 1998). More number of side shoots resulted in more number of leaves and flower. Similar observations had also been reported by Banon et al., (2001) in N. oleander, Krunananda and Peiris (2010) in Pot Poinsettia as well as Kour et al., (2012) in marigold. Due to more number of leaves and flower, the duration of flowering increased significantly. In double pinched plants there was culmination of apical dominance and accordingly the plants produced more number of lateral branches instead of attaining upward growth. Hence, increases the plant spread significantly in comparison to control and other methods of pinching. The present results are in close agreement with the earlier findings of Singh et al., (2005) in carnation, Bhat and Shephered (2007) and Maharnor et al., (2011) in African marigold and Kumar et al., (2014) in Stevia.

The maximum height $(49.84 \mathrm{~cm})$ observed in unpinched plants could be due to the reason that apical dominance had exhibited its superiority over single and no pinching. Whereas, in case of double pinching (30.63 $\mathrm{cm})$ there was culmination of apical dominance and accordingly the plants could not attain sufficient height and hence remained shorter comparatively. Shoot decapitation following double pinching had resulted in lower auxin production, which further reduced the apical control and hence ultimately led to reduction in plant height. Similar findings of significant reduction in plant height due to double pinching were reported by Ryagi et al., (2007) in carnation, Maharnor et al., (2011) in African marigold and Rathore et al., (2011) in marigold cv. 'Pusa Basanti Gainda'.

Pinching is known to delay development of flower buds and the flowering as well and could be ascribed to the reasons that there is culmination of apical dominance that results into development of more number of secondary and side branches following pinching. These secondary and side branches took more time to attain sufficient vegetative growth as well as development of reproductive buds. So, needs more time to develop flower buds. Hence, more number of days was taken for visible bud formation (113.15 days) and flowering (128.16 days) in double pinched plants. These findings are in confirmation with the results of Grewal et al., (2004) in chrysanthemum where pinched plants took more number of days (138.35 days) to bud break than unpinched plants (129.74 days) and Dalal et al., (2006) in carnation cv. 'Yellow Solar'.

Among benzyl adenine treatments, plants treated with 200 ppm dose of benzyl adenine found most suitable for the growth and flowering parameters of Barleria cristata L. 'Alba'(Table 1,2\&3), like; number of side shoots (19.87), number of leaves (91.37), number of flower per cluster (8.47), number of flower cluster per plant (23.88), number of flower opened at a time per plant (20.40), flower size (2.82), plant spread $(25.81 \mathrm{~cm})$, duration of flowering (33.92) and pot presentability score (72.22) were best in this treatment. It is well documented fact that exogenous applications of cytokinins in general and benzyl adenine in particular are known to increase the plant biomass especially in terms of development and production of lateral buds which in due course of time develops into side shoots. 
Hence, there is production of more number of side shoots (19.87) with the application of benzyl adenine at $200 \mathrm{ppm}$ and also increase number of leaves (90.90) due to higher rate of mitosis (Table 1). Moreover number of flowers clusters (23.88) and number of flower per cluster (8.47) also increased with the increase of side shoots and leaves (Table 2). Similar kind of an increase with the application of benzyl adenine were reported by Jeffcoat (1977), Baskaran and Misra (2007) in gladiolus, Ibrahim et al., (2010) in croton plants, Soad et al., (2010) in Codiaeum variegatum, Mazher et al., (2011) in Salvia officinalis, Lone et al., (2011) in Barleria prionitis, Wróblewska (2013) in Gaura lindheimeri and Newton and Runkle (2015).

Shortest plants $(39.35 \mathrm{~cm})$ were reported with the application of $200 \mathrm{ppm}$ of benzyl adenine cytokinins in general stimulate branching and therefore may competitively limit upward growth. They are also known to be involved in breaking the apical dominance and promote the growth of lateral buds. Cytokinins also act in balance with auxins to control apical dominance (Sachs and Thimann, 1967).

The present study indicate that the plants treated with paclobutrazol have significant effect on growth and flowering parameters of Barleria cristata L. 'Alba' (Table 1,2\&3). The parameters like; number of leaves (90.95), number of flower per cluster (8.75), number of flower opened at a time per plant (20.30) and duration of flowering (33.35) were best in treatment of paclobutral @ 200 ppm. The production of more leaves in plants receiving paclobutrazol @ 200 ppm could be ascribe to the reason that exogenous application of paclobutrazol at higher doses had culminated the effect of apical dominance leading to diversion of growth promoting hormones like auxins towards the side shoots. So much so there were more number of shoots with the application of paclobutrazol Whereas, parameters like number of side shoots
(18.42), number of flower cluster per plant (22.41) and pot presentability score (69.78) found maximum in plants treated with paclobutrazol@100 ppm. Paclobutrazol is a retardant and is known to suppress the influence of apical dominance resulting in the increase in development of lateral buds which in the due course of time developed into side shoots. Similar kind of increase in number of branches had also been reported by Nichal (2010) in Barleria cristata, Mishra and Mishra (2006) in china aster cv. 'Poornima', Singh et al., (2016) and Abd El-Aal and Mohamed (2017) in geranium.

Among paclobutrazol treatments, tallest plants $(46.20 \mathrm{~cm})$ were recorded without the application of paclobutrazol and shortest plants $(36.61 \mathrm{~cm})$ were reported with paclobutrazol@200 ppm. The application of paclobutrazol had culminated the effect of apical dominance hence resulted in shorter plant height. The largest flowers size (3.15 $\mathrm{cm}$ ) was recorded in plants without the application of paclobutrazol and smallest flowers $(2.26 \mathrm{~cm})$ were produced with 200 ppm dose of paclobutrazol. Paclobutrazol being a retardant had exhibited its applicability to slow down various developmental activities and they have been manifested in terms of various vegetative and flowering characteristics like plant height, shoot length, leaf size as well as flower size. These findings get the support of Kose and Kostak (2000) in Nerium oleander, Bekheta et al., (2008) in gerbera, Mansuroglu et al., (2009) in Consolida orientalis, Nazarudin (2012) in Hibiscus rosa sinensis as well as Lenzi et al., (2015) in Dianthus barbatus $\times$ chinensis, who reported significant reduction in plant height with the application of paclobutrazol.

Data presented in Table-4 revealed significant interaction effect of pinching, benzyl adenine and paclobutrazol on growth and flowering parameters of Barleria cristata L. 'Alba'. In 
this, the double pinched plants coupled with the application of BA @ 200 ppm and paclobutrazol @200 ppm had recorded maximum values for number of side shoots per plant (25.00), number of leaves per plant (110.80), number of flower clusters per plant (28.87), number of flowers per cluster (11.07), number of flowers per plant opened at a time (28.93) and duration of flowering (36.33).

Maximum plant height $(57.71 \mathrm{~cm})$ was recorded without the application of benzyl adenine and paclobutrazol in the unpinched plants (control plants). Whereas, shortest plants $(25.68 \mathrm{~cm})$ were observed with 200 ppm concentration of paclobutrazol and without the application of benzyl adenine following double pinching. It is evident that applications of paclobutrazol especially at higher concentrations and employing double pinching reduced plant height considerably as compared to control. Although, the interactive effects double pinching and higher doses of paclobutrazol as well as increased concentrations of benzyl adenine applications also decreased plant height reasonably, however, results obtained indicate that paclobutrazol and pinching treatments have exhibited some synergistic effects, whereas, same seems to be not quite conclusive with the combined effects of benzyl adenine with the pinching and paclobutrazol.

Table.1

\begin{tabular}{|c|c|c|}
\hline Parameters & Description & $\begin{array}{l}\text { Maximum } \\
\text { Points }\end{array}$ \\
\hline $\begin{array}{l}\text { a) Appearance } \\
\text { as whole plant }\end{array}$ & $\begin{array}{l}\text { i) Fresh appearance, no indication of senescence, } \\
\text { mechanical and insect damage in inflorescence/stem } \\
\text { ii) Fresh appearance but some indication of senescence }\end{array}$ & $\begin{array}{l}20 \\
12\end{array}$ \\
\hline $\begin{array}{l}\text { b) Flowering } \\
\text { attributes } \\
\text { ( I) Number of } \\
\text { flowers per } \\
\text { plant }\end{array}$ & $\begin{array}{l}\text { Scoring of the pots at the time of peak flowering (number } \\
\text { of inflorescences/ pot open at a time) } \\
\text { i) } 23-30 \\
\text { ii) } 15-23 \\
\text { iii) }<15\end{array}$ & $\begin{array}{l}20 \\
12 \\
8\end{array}$ \\
\hline $\begin{array}{l}\text { (II) Size of } \\
\text { flower }\end{array}$ & $\begin{array}{l}\text { i) Large }(>2.5 \mathrm{~cm}) \\
\text { ii) Medium }(\geq 2.0-\leq 2.5 \mathrm{~cm}) \\
\text { iii) Small }(\leq 2.0 \mathrm{~cm})\end{array}$ & $\begin{array}{l}20 \\
12 \\
8\end{array}$ \\
\hline c) Form & $\begin{array}{l}\text { i) Plant in balance with pot, neither too large nor too } \\
\text { small, (generally } 1.5 \text { times the height of the container } \\
\text { ii) Plants to large or to small and less plant spread }\end{array}$ & $\begin{array}{l}20 \\
12\end{array}$ \\
\hline $\begin{array}{l}\text { d) Stem and } \\
\text { foliage }\end{array}$ & $\begin{array}{l}\text { i) Plant self-supportive with strong stem. Foliage without } \\
\text { chlorosis and necrosis } \\
\text { ii) Plants not self-supportive with less strong stems. } \\
\text { Foliage with sulfur deficiency, unhealthy and not free } \\
\text { from infestation of insect-pests, diseases and bruises etc. }\end{array}$ & $\begin{array}{l}20 \\
12\end{array}$ \\
\hline
\end{tabular}


Table.1 Effect of pinching, benzyl adenine and paclobutrazol on vegetative and flowering characteristics of Barleria cristata L. 'Alba'

\begin{tabular}{|c|c|c|c|c|}
\hline $\begin{array}{l}\text { Plant Growth } \\
\text { Characteristics }\end{array}$ & $\begin{array}{l}\text { Plant height } \\
\text { (cm) }\end{array}$ & $\begin{array}{c}\text { Number of } \\
\text { side shoots } \\
\text { per plant }\end{array}$ & $\begin{array}{l}\text { Number of leaves } \\
\text { per plant at the } \\
\text { time of flowering }\end{array}$ & $\begin{array}{l}\text { Plant spread } \\
\text { (cm) }\end{array}$ \\
\hline \multicolumn{5}{|l|}{ Pinching (P) } \\
\hline No pinching $\left(P_{1}\right)$ & 49.84 & 13.06 & 66.98 & 16.16 \\
\hline Single pinching $\left(\mathbf{P}_{2}\right)$ & 42.84 & 17.68 & 82.65 & 21.65 \\
\hline Double pinching $\left(\mathbf{P}_{3}\right)$ & 30.63 & 21.30 & 91.37 & 27.52 \\
\hline \multicolumn{5}{|l|}{ Benzyl Adenine (BA) } \\
\hline $0 \mathbf{p p m}\left(\mathbf{B} \mathbf{A}_{1}\right)$ & 43.11 & 14.95 & 69.31 & 16.86 \\
\hline $100 \operatorname{ppm}\left(\mathrm{BA}_{2}\right)$ & 40.85 & 17.25 & 80.79 & 22.67 \\
\hline $200 \operatorname{ppm}\left(\mathbf{B A}_{3}\right)$ & 39.35 & 19.87 & 90.90 & 25.81 \\
\hline \multicolumn{5}{|l|}{ Paclobutrazol (PBZ) } \\
\hline 0 ppm $\left(\mathrm{PBZ}_{1}\right)$ & 46.20 & 15.22 & 69.88 & 23.09 \\
\hline $100 \operatorname{ppm}\left(\mathrm{PBZ}_{2}\right)$ & 39.57 & 18.42 & 80.17 & 22.37 \\
\hline $200 \operatorname{ppm}\left(\mathrm{PBZ}_{3}\right)$ & 36.61 & 18.39 & 90.95 & 19.88 \\
\hline \multicolumn{5}{|l|}{ LSD $_{0.05:}$} \\
\hline Pinching (P) & 1.32 & 0.86 & 2.05 & 0.54 \\
\hline Benzyl Adenine (BA) & 1.32 & 0.86 & 2.05 & 0.54 \\
\hline Paclobutrazol (PBZ) & 1.32 & 0.86 & 2.05 & 0.54 \\
\hline
\end{tabular}

Table.2 Effect of pinching, benzyl adenine and paclobutrazol on vegetative and flowering characteristics of Barleria cristata L. 'Alba'

\begin{tabular}{|c|c|c|c|c|}
\hline $\begin{array}{l}\text { Plant Growth } \\
\text { Characteristics }\end{array}$ & $\begin{array}{l}\text { Number of days } \\
\text { taken for visible } \\
\text { bud formation }\end{array}$ & $\begin{array}{l}\text { Number of } \\
\text { days taken for } \\
\text { flowering }\end{array}$ & $\begin{array}{c}\text { Number of } \\
\text { flower clusters } \\
\text { per plant }\end{array}$ & $\begin{array}{c}\text { Number of } \\
\text { flowers per } \\
\text { cluster }\end{array}$ \\
\hline \multicolumn{5}{|l|}{ Pinching (P) } \\
\hline No pinching $\left(\mathbf{P}_{1}\right)$ & 98.15 & 113.27 & 16.66 & 6.38 \\
\hline Single pinching $\left(\mathbf{P}_{2}\right)$ & 107.47 & 122.89 & 21.47 & 7.70 \\
\hline Double pinching $\left(\mathbf{P}_{3}\right)$ & 113.15 & 128.16 & 25.37 & 9.15 \\
\hline \multicolumn{5}{|l|}{ Benzyl Adenine (BA) } \\
\hline 0 ppm $\left(\mathbf{B} \mathbf{A}_{1}\right)$ & 104.99 & 120.16 & 18.54 & 6.73 \\
\hline $100 \mathrm{ppm}\left(\mathrm{BA}_{2}\right)$ & 107.57 & 122.87 & 21.07 & 8.01 \\
\hline $200 \operatorname{ppm}\left(\mathbf{B A}_{3}\right)$ & 106.20 & 121.29 & 23.88 & 8.47 \\
\hline \multicolumn{5}{|l|}{ Paclobutrazol (PBZ) } \\
\hline 0 ppm $\left(\mathrm{PBZ}_{1}\right)$ & 102.85 & 118.19 & 18.71 & 6.64 \\
\hline $100 \operatorname{ppm}\left(\mathrm{PBZ}_{2}\right)$ & 106.06 & 121.32 & 22.41 & 7.83 \\
\hline $200 \operatorname{ppm}\left(\mathrm{PBZ}_{3}\right)$ & 109.85 & 125.14 & 22.37 & 8.75 \\
\hline \multicolumn{5}{|l|}{$\mathbf{L S D}_{0.05:}$} \\
\hline Pinching (P) & 0.80 & 0.99 & 0.80 & 0.16 \\
\hline Benzyl Adenine (BA) & 0.80 & 0.99 & 0.80 & 0.16 \\
\hline Paclobutrazol (PBZ) & 0.80 & 0.99 & 0.80 & 0.16 \\
\hline
\end{tabular}


Table.3 Effect of pinching, benzyl adenine and paclobutrazol on vegetative and flowering characteristics of Barleria cristata L. 'Alba'

\begin{tabular}{|c|c|c|c|c|}
\hline $\begin{array}{l}\text { Plant Growth } \\
\text { Characteristics }\end{array}$ & $\begin{array}{l}\text { Number of } \\
\text { flowers opened } \\
\text { at a time }\end{array}$ & $\begin{array}{c}\text { Duration of } \\
\text { flowering } \\
\text { (days) }\end{array}$ & $\begin{array}{l}\text { Flower size } \\
\text { (cm) }\end{array}$ & $\begin{array}{c}\text { Pot } \\
\text { Presentability }\end{array}$ \\
\hline No pinching $\left(\mathbf{P}_{1}\right)$ & 12.51 & 30.93 & 2.79 & 60.00 \\
\hline Single pinching $\left(\mathbf{P}_{2}\right)$ & 18.37 & 32.09 & 2.70 & 67.11 \\
\hline Double pinching $\left(\mathbf{P}_{3}\right)$ & 24.27 & 33.32 & 2.61 & 78.89 \\
\hline $0 \operatorname{ppm}\left(\mathbf{B A}_{1}\right)$ & 15.98 & 29.96 & 2.48 & 64.11 \\
\hline $100 \mathrm{ppm}\left(\mathbf{B A}_{2}\right)$ & 18.76 & 32.47 & 2.79 & 69.67 \\
\hline $200 \operatorname{ppm}\left(\mathbf{B A}_{3}\right)$ & 20.40 & 33.92 & 2.82 & 72.22 \\
\hline 0 ppm $\left(\mathrm{PBZ}_{1}\right)$ & 15.66 & 30.44 & 3.15 & 67.78 \\
\hline $100 \operatorname{ppm}\left(\mathrm{PBZ}_{2}\right)$ & 19.19 & 32.56 & 2.69 & 69.78 \\
\hline $200 \mathrm{ppm}\left(\mathrm{PBZ}_{3}\right)$ & 20.30 & 33.35 & 2.26 & 68.44 \\
\hline \multicolumn{5}{|l|}{ LSD $_{0.05:}$} \\
\hline Pinching (P) & 0.55 & 0.23 & 0.05 & 0.55 \\
\hline Benzyl Adenine (BA) & 0.55 & 0.23 & 0.05 & 0.55 \\
\hline Paclobutrazol (PBZ) & 0.55 & 0.23 & 0.05 & 0.55 \\
\hline
\end{tabular}

Table.4 Interaction effect of pinching, benzyl adenine and paclobutrazol on vegetative and flowering characteristics of Barleria cristata L. 'Alba'

\begin{tabular}{|c|c|c|c|c|c|c|c|c|c|}
\hline \multicolumn{10}{|c|}{ Plant Height } \\
\hline \multirow{3}{*}{$\begin{array}{c}\text { Paclobutrazol } \\
\text { (ppm) }\end{array}$} & \multirow{2}{*}{\multicolumn{3}{|c|}{$\begin{array}{c}\text { No pinch } \\
\text { Benzyl adenine (ppm) }\end{array}$}} & \multirow{2}{*}{\multicolumn{3}{|c|}{$\begin{array}{c}\text { Single Pinch } \\
\text { Benzyl adenine (ppm) }\end{array}$}} & \multirow{2}{*}{\multicolumn{3}{|c|}{$\begin{array}{c}\text { Double Pinch } \\
\text { Benzyl adenine (ppm) }\end{array}$}} \\
\hline & & & & & & & & & \\
\hline & \multicolumn{3}{|c|}{$0 \quad 100$} & 0 & 100 & 200 & o & 100 & 200 \\
\hline $\mathbf{0}$ & 57.71 & 52.01 & 49.81 & 51.62 & 47.09 & 45.91 & 44.73 & 34.91 & 32.05 \\
\hline 100 & 47.03 & 50.08 & 48.95 & 43.19 & 41.37 & 40.15 & 29.68 & 28.39 & 27.32 \\
\hline 200 & 41.79 & 47.27 & 45.57 & 38.26 & 39.64 & 38.35 & 25.68 & 26.87 & 26.05 \\
\hline LSD $_{0.05:}$ & \multicolumn{6}{|l|}{3.50} & & & \\
\hline \multicolumn{10}{|c|}{ Number of side shoots per plant } \\
\hline $\mathbf{0}$ & 8.27 & 11.93 & 13.00 & 11.67 & 15.93 & 19.07 & 14.07 & 19.93 & 23.13 \\
\hline 100 & 12.73 & 13.20 & 16.53 & 18.07 & 17.93 & 20.00 & 22.07 & 21.60 & 23.67 \\
\hline 200 & 10.73 & 14.13 & 17.00 & 16.93 & 18.40 & 21.13 & 20.00 & 22.20 & 25.00 \\
\hline $\mathbf{L S D}_{0.05:}$ & \multicolumn{6}{|l|}{2.60} & & & \\
\hline \multicolumn{10}{|c|}{ Number of days for visible bud formation } \\
\hline $\mathbf{0}$ & 91.60 & 96.00 & 95.07 & 99.87 & 107.13 & 105.73 & 106.67 & 112.27 & 111.33 \\
\hline
\end{tabular}




\begin{tabular}{|c|c|c|c|c|c|c|c|c|c|}
\hline 100 & 96.67 & 100.733 & 98.00 & 109.47 & 106.67 & 105.27 & 113.67 & 110.40 & 113.67 \\
\hline 200 & 99.20 & 104.80 & 101.27 & 112.27 & 111.33 & 109.47 & 115.53 & 118.80 & 116.00 \\
\hline LSD $_{0.05:}$ & \multicolumn{9}{|l|}{2.41} \\
\hline \multicolumn{10}{|c|}{ Number of days taken for flowering } \\
\hline 0 & 106.60 & 111.13 & 110.07 & 114.87 & 122.60 & 121.27 & 122.33 & 127.87 & 127.00 \\
\hline 100 & 111.67 & 115.93 & 113.00 & 124.87 & 122.33 & 121.40 & 128.07 & 125.60 & 129.00 \\
\hline 200 & 114.33 & 120.20 & 116.47 & 127.80 & 126.40 & 124.47 & 130.87 & 133.80 & 131.93 \\
\hline LSD $_{0.05:}$ & \multicolumn{9}{|l|}{2.97} \\
\hline \multicolumn{10}{|c|}{ Number of flower per cluster } \\
\hline 0 & 5.27 & 5.47 & 5.93 & 5.80 & 6.93 & 7.00 & 6.13 & 8.47 & 8.80 \\
\hline 100 & 5.40 & 6.67 & 7.00 & 6.67 & 7.93 & 8.67 & 8.20 & 9.87 & 10.07 \\
\hline 200 & 6.20 & 7.40 & 8.07 & 7.80 & 8.80 & 9.67 & 9.13 & 10.60 & 11.07 \\
\hline LSD $_{0.05:}$ & \multicolumn{9}{|l|}{0.48} \\
\hline \multicolumn{10}{|c|}{ Plant spread } \\
\hline 0 & 13.65 & 17.10 & 21.04 & 18.30 & 23.39 & 27.00 & 22.40 & 31.22 & 33.80 \\
\hline 100 & 13.36 & 16.36 & 20.03 & 17.58 & 22.95 & 26.30 & 21.76 & 30.81 & 32.19 \\
\hline 200 & 11.92 & 14.04 & 18.03 & 14.22 & 20.55 & 24.59 & 18.57 & 27.70 & 29.28 \\
\hline $\mathbf{L S D}_{0.05:}$ & \multicolumn{9}{|l|}{1.61} \\
\hline \multicolumn{10}{|c|}{ Pot presentability Score (100) } \\
\hline $\mathbf{0}$ & 57.00 & 60.00 & 62.00 & 59.00 & 66.00 & 76.00 & 69.00 & 78.00 & 83.00 \\
\hline 100 & 59.00 & 62.00 & 61.00 & 68.00 & 66.00 & 64.00 & 73.00 & 88.00 & 87.00 \\
\hline 200 & 58.00 & 61.00 & 60.00 & 67.00 & 65.00 & 73.00 & 67.00 & 81.00 & 84.00 \\
\hline LSD $_{0.05:}$ & \multicolumn{9}{|l|}{1.64} \\
\hline
\end{tabular}

In contrast, minimum time taken for visible bud formation (91.60 days) and number of days taken for flowering (106.60 days) were observed in unpinched plants without the applications of paclobutrazol and benzyl adenine. In general, the interaction results revealed that highest dose of paclobutrazol along with double pinching delayed flowering. Also, the applications of benzyl adenine in moderate concentration (100 ppm) resulted in delaying of flowering. But on the contrary, the applications of benzyl adenine at higher concentrations (200 ppm) had stimulated the flowering. Hence took lesser time comparatively.

However, maximum pot presentability score (88.00) was found in those plants which exhibited optimum plant height $(28.39 \mathrm{~cm})$ and plant spread (30.81) along with other pot presentability attributes with the application of double pinching, paclobutrazol and BA @ 100 ppm each (Conover CA, 1986).

\section{References}

Abd El-Aal MMM and Mohamed YFY. 2017. Effect of pinching and paclobutrazol on 
growth, flowering, anatomy and chemical compositions of potted geranium (Pelargonium zonal L.) plant. International Journal of Plant \& Soil Science 17:1-22.

Banon AS, Franko LJA and Fernandez HJA. 2001. Growth and leaf colour responses of oleander (Nerium oleander L.) to pinching and chlormequat chloride treatment. Acta Horticulturae 559:155-160.

Baskaran V and Misra RL. 2007. Effect of plant growth regulators on growth and flowering of gladiolus. Indian Journal of Horticulture 64:479-482.

Bekheta MA, Abbas S, El-Kobisy OS, and Mahgoub MH. 2008. Influence of selenium and paclobutrazol on growth, metabolic activities and anatomical characters of gerbera (Gerbera jamesonii L.). Australian Journal Basic Applied Sciences 2:12841297.

Bhat ZA and Shephered H. 2007. Effect of pinching on growth, flowering, seed yield and quality trails in African marigold (TageteserectaL.). Journal of Ornamental Horticulture 10:197-198.

Bhattacharjee SK and DE LC. 2003. Advanced Commercial Floriculture. Avishkar Publication, Jaipur, India. pp. 299-308.

Conover CA. 1986. Quality. Acta Horticulturae 181: 201-205.

Dalal SR, Nandre DR, Bharad SG, Utgikar S and Shinde RD. 2006. Effect of pinching on carnation cv. 'Yellow Solar' under polyhouse condition. International Journal of agriculture Science 2:356-357.

Grewal HS, Kumar R and Singh H. 2004. Effect of nitrogen, planting time and pinching on flower production in chrysanthemum cv. 'Flirt'. Journal of Ornamental Horticulture 7:196-199.

Ibrahim SMM, Taha LS and Farahat MM. 2010. Vegetative growth and chemical constituents of croton plants as affected by foliar application of benzyl adenine and gibberellic acid. Journal of American Science 6:126-130.

Jeffcoat B. 1977. Effects of some growth regulators on tiller bud elongation in cereals. New Phytologist - NEW PHYTOL 79:239-245.

Kose $\mathrm{H}$ and Kostak S. 2000. The propagation of
Nerium oleander L. cv. 'Variegata' with cuttings and effects of paclobutrazol on growth and flowering. Anadolu Agency 10:31-42.

Kour R, Khajuria S, Sharma M and Sharma A. 2012. Effect of spacing and pinching on flower production in marigold cv. 'PusaNarangiGainda' in mid-hills of $\mathrm{J} \& \mathrm{~K}$ state. Asian Journals of Horticulture 7:307309.

Krunananda DP and Peiris SE. 2010. Effects of pinching, cycocel and B-nine treatments on branching habit of pot poinsettia. Tropical Agriculture Research 21:284-292.

Kumar A and Purohit SS. 1998. Plant physiology: fundamentals and application. Agrobios Publication. Jodhpur. 409p.

Kumar R, Sharma S and Sharma M. 2014. Growth and yield of natural-sweetener plant stevia as affected by pinching. Indian Journal of Plant Physiology 19:119-126.

Lenzi A, Nannicini M, Mazzeo P and Baldi A. 2015. Effect of paclobutrazol in potted plants of four cultivars of Dianthus barbatus $\times$ chinensis. European Journal of Horticulture Sciences 80:87-93.

Lone SA, Yadav AS, Badkhane Y, Sharma AK, Bakhshi SH and Raghuwanshi DK. 2011. Effect of different plant growth regulators on in-vitro propagation of Barleriaprionitis L. - a threatened medicinal plant. International Journal of Pharma and Bio Sciences 2:438-444.

Maharnor SI, Chopde N, Thakre S and Raut PD. 2011. Effect of Nitrogen and pinching on growth and yield of African marigold. Asian Journals of Horticulture 6:43-45.

Mansuroglu S, Karaguzel O, Ortacesme V and Sayan MS. 2009. Effect of paclobutrazol on flowering, leaf and flower colour of consolidaorientalis. Pakistan Journal of Botany 41:2323-2332.

Mazher AA, Zaghloul SM, Mahmoud SA and Siam HS. 2011. Stimulatory effect of kinetin, ascorbic acid and glutamic acid on growth and chemical constituents of Salvia officinalis, Lavandula officinalis and Tagetes minuta plants. American-Eurasian Journal of Agriculture \& Environmental Sciences 10:318-323.

Mishra DK and Mishra HR. 2006. Growth and 
flowering response of China aster (Callistephus chinensis L. Nees) to paclobutrazol. Journal of Ornamental Horticulture 9:63-65.

Nazarudin A. 2012. Plant growth retardants effect on growth and flowering of potted Hibiscus rosasinensis. Journal Tropical Plant Physiology 4:29-40.

Newton LA and Runkle ES. 2015. Effects of BA on vegetative growth and flowering of potted Miltoniopsis orchids. Acta Horticulture 1078:121-128.

Nichal V. 2010. Effect of growing media, pinching and paclobutrazol on growth and flowering of Barleria cristata L. MSc Thesis submitted to Dr YS Parmar University of Horticulture and Forestry, Nauni, Solan, Himachal Pradesh. 94p.

Pullaiah T. 2006. Encyclopaedia of world medicinal plants. Regency Publication, New Delhi, India 1:520

Rathore I, Mishra A, Moond SK and Bhatnagar P. 2011. Studies on effect of pinching and plant bioregulators on growth and flowering of marigold (Tagetes erecta L.) cv. 'PusaBasantiGainda'. Indian Journal of Horticulture 43:52-55.

Ryagi VY, Mantur SM and Reddy BS. 2007. Effect of pinching on growth, yield and quality of flowers of carnation varieties grown under polyhouse. Karnataka Journal of Agriculture Science 20:816-818.

Sachs T and Thimann KV. 1967. The role of auxins and cytokinins in the release of buds from dominance. American Journal of Botany 54:136-144.
Sharma P, Thakur P, Dhiman, SR and Gupta YC. 2013. Effect of nitrogen, phosphorus and potassium on growth and flowering of Barleria cristata Linn. Indian Journal of Horticulture 70:442- 447.

Singh R, Kumar R and Singh K. 2005. Effect of pinching and nitrogen application on growth and flower production in carnation. Journal of Ornamental Horticulture 8: 239240.

Singh, J, Dilta B, Gupta Y, Sharma B, Baweja H and Kaushal S. 2016. Effect of growing media and paclobutrazol on growth, flowering and pot presentability of geranium, Pelargonium $\times$ hortorum LH Bailey. Internatinal Journal of Farm Science 6:128-136

Soad IMM, Lobna TS and Farahat MM. 2010. Vegetative growth and chemical constituents of Croton plants as affected by foliar application of BA and gibberellic acid. Journal of American Science 126-130.

Thakur P, Dhiman SR, Kashyap B and Gupta YC. 2009. Grow Barleria for exquisite beauty. Indian Horticulture 54:17-18.

Thakur P, Nichal V, Dhiman SR and Gupta YC. 2015. Effect of growing media, pinching and paclobutrazol on growth and flowering of Barleria cristata L. as pot plant. Indian Journal of Agricultural Sciences 85:833837.

Wróblewska K. 2013. BA effect on rooting and axillary shoot outgrowth of Gauralindheimeri Engelm. A. Gray cuttings. Acta Scientiarum Polonorum Hortorum Cultus 12:127-136.

\section{How to cite this article:}

Hitesh Bhardwaj, Priyanka Thakur, S. R. Dhiman, Y. C. Gupta, B. S. Dilta, A. Thakur and Rahul Chandel. 2020. Benzyl Adenine and Paclobutrazol Coupled with Shoot Decapitation Affects Growth and Flowering in Barleria cristata L. 'Alba'. Int.J.Curr.Microbiol.App.Sci. 9(02): 2007-2017. doi: https://doi.org/10.20546/ijcmas.2020.902.229 